\title{
ANAK BERHADAPAN HUKUM DALAM PERSPEKTIF RESTORATIVE JUSTICE
}

\section{Pristiwiyanto}

STAI Al Azhar, Menganti Gresik_Jl. Raya Menganti Krajan No 447 Gresik

pristiwiyanto@gmail.com

\begin{abstract}
ABSTRACK
Children are the mandate and blessings of God Almighty, which is inherent in their dignity and dignity as whole human beings. A country representing an institution / institution that is responsible for meeting the financial needs of its people should be able to make a budget that can realize the protection and welfare of children in the form of good health protection from philosophical aspects, right from sociological aspects, and correct from normative aspects of solving and protection of children in conflict with the law. Children who are dealing with the law are very vulnerable to handling that is not in accordance with the child's psychology or psychology. To decide the need for conflict with children to correct cases of crime I conflict with the law. Crimes are against the law Crimes are often followed up by experts Criminal prosecutions of doubleedged double-edged swords or there are other debates saying the murder law will slice their own flesh wrong compilation in its application. the laws that children do often cause legal problems. Law enforcement officials are often absent in the action against lawsuits committed by children. Regulations taken in handling cases of children are often distorted and not involved by the authorities in the field, so it happens with children's rights and does not damage the child's future.
\end{abstract}

Keywords: Children, Law, Retorative.

\begin{abstract}
ABSTRAK
Anak adalah amanah dan karunia Tuhan Yang Maha Esa, yang dalam dirinya melekat harkat dan martabat sebagai manusia seutuhnya. Negara yang merupakan suatu lembaga/institusi tertinggi dan bertanggung jawab besar terhadap pemenuhan kesejahteraan serta perlindungan terhadap bangsanya sudah selayaknya harus mampu untuk membuat suatu kebijakan yang bisa mewujudkan perlindungan dan kesejahteraan anak dalam bentuk dukungan kelembagaan dan peraturan perundang-undangan yang dapat menjamin pelaksanaannya.Bagaimana cara yang baik dari aspek filosofis, tepat dari aspek sosiologis, dan benar dari aspek normatif mengatasi dan melindungi anak yang berhadapan dengan hukum. Anak yang berhadapan dengan hukum rentan sekali terhadap perlakuan-perlakuan yang tidak patut dan tidak sesuai dengan psikis atau kejiwaan anak tersebut. Untuk itulah perlu adanya perlindungan terhadap anak yang mengalami kasus-kasus tindak pidanal konflik dengan hukum. Tindak pidana adalah pelanggaran terhadap hukum pidana dimana sering diungkapkan oleh para pakar pidana bahwa hukum pidana itu ibarat pedang bermata dua atau ada ungkapan lain yang mengatakan hukum pidana itu akan mengiris dagingnya sendiri ketika salah dalam penerapannya.Berbagai kasus yang ada terutama yang terkait dengan suatu pelanggaran hukum yang dilakukan anak-anak sering menimbulkan suatu problem hukum. Aparat penegak hukum sering tidak ada kesamaan dalam penindakan terhadap pelanggaran yang dilakukan oleh anak-anak. Regulasi yang dijadikan pedoman dalam penanganan kasus anak-anak sering disimpangi bahkan belum dipahami secara mendalam oleh aparat dilapangan, sehingga terjadi pelanggaran terhadap hak asasi anak-anak dan tidak jarang merusak masa depan anak.
\end{abstract}

Kata Kunci: Anak, Hukum, Retorative.

Program Studi Pendidikan Guru Madrasah Ibtidaiyah

STAI Al-Azhar Menganti Gresik, Indonesia

\section{Pendahuluan}

Anak adalah amanah dan karunia Tuhan Yang Maha Esa, yang dalam dirinya melekat harkat dan martabat sebagai manusia seutuhnya. Sisi lain yang perlu diperhatikan yakni anak adalah tunas, potensi dan generasi penerus cita-cita perjuangan bangsa, memiliki peran strategis dan mempunyai ciri serta sifat khusus yang menjamin kelangsungan eksistensi bangsa dan negara pada masa depan. Agar setiap anak kelak mampu memiliki tanggung jawab dan mampu menghadapi dinamika zaman, maka ia perlu mendapat kesempatan yang 
ZAHRA: Research And Tought Elmentary School Of Islam Journal Vol. (1 ) (1), (Maret)(2020), (Halaman)(1-7)| 2 seluas-luasnya untuk tumbuh dan berkembang secara optimal, baik fisik, mental maupun sosial, dan berakhlak mulia, perlu dilakukan upaya perlindungan serta untuk mewujudkan kesejahteraan anak dengan memberikan jaminan terhadap pemenuhan hakhaknya serta adanya perlakuan tanpa diskriminasi.

Negara yang merupakan suatu lembaga/institusi tertinggi dan bertanggung jawab besar terhadap pemenuhan kesejahteraan serta perlindungan terhadap bangsanya sudah selayaknya harus mampu untuk membuat suatu kebijakan yang bisa mewujudkan perlindungan dan kesejahteraan anak dalam bentuk dukungan kelembagaan dan peraturan perundang-undangan yang dapat menjamin pelaksanaannya. Bentuk dari regulasi negara terhadap perlindungan anak tersebut lahirlah sebuah hukum berupa Undang-Undang Nomor 23 tahun 2002 tentang perlindungan anak. Pengertian perlindungan anak sesuai dengan Undang-Undang tersebut adalah: segala kegiatan untuk menjamin dan melindungi anak dan hak-haknya agar dapat hidup, tumbuh, berkembang, dan berpartisipasi secara optimal sesuai dangan harkat dan martabat kemanusiaan, serta mendapat perlindungan dari kekerasan dan diskriminasi (UUD No. 23 Tahun 2002). Dalam realitas kehidupan anak, sering ditemukan suatu peristiwa hukum yang tidak jarang memunculkan perbuatan hukum yang mengakibatkan anak tersebut berhadapan dengan hukum, terlepas sebagai pelaku, korban, dan saksi. Kenyataan ini harus mendapat perhatian serius karena posisi anak tersebut yang belum mampu untuk melindungi dirinya sendiri dan secara kejiwaan memang belum siap untuk berhadapan dengan hukum karena ada eksesekses yang perlu dihindari, supaya perkembangan dan pertumbuhan anak tidak mengalami gangguan fisik, mental, maupun sosial.

Akhir-akhir ini banyak kita jumpai kasus-kasus berkaitan dengan anak yang berhadapan dengan hukum dalam pemberitaan-pemberitaan yang cukup besar-besaran baik melalui media cetak maupun elektronik, misal kasus AAL anak yang dituduh mencuri sandal jepit sehingga harus masuk tahanan, kasus di Si junjung Sumatra Barat, yaitu Faisal 14 tahun dan kakaknya Busri M Zein 17 tahun gantung diri dalam tahanan Polsek setempat karena disangka melakukan pencurian kotak amal dan kakaknya ditangkap dengan sangkaan pencurian kendaraan bermotor (Jawa Pos: 2012). Kasuskasus lain yang tidak sempat terekspose masih banyak jumlahnya, hal ini bisa disinyalir dari informasi yang disampaikan Komisi Perlindungan Anak Indonesia (KPAI) bahwa jumlah anak yang berhadapan dengan hukum terus meningkat. Rata-rata setiap tahun tidak kurang dari 7000 anak masuk penjara. Anak sebagai tunas, potensi dan penerus cita-cita perjuangan bangsa, memiliki peran strategis sudah selayaknya harus memperoleh perlidungan ketika berhadapan dengan hukum, dengan 
ZAHRA: Research And Tought Elmentary School Of Islam Journal Vol. (1 ) (1), (Maret)(2020), (Halaman)(1-7)| 3 demikian maka bentuk rumusan masalah yang dapat diangkat dalam penulisan ini, ialah : Bagaimana cara yang baik dari aspek filosofis, tepat dari aspek sosiologis, dan benar dari aspek normatif mengatasi dan melindungi anak yang berhadapan dengan hukum?

\section{Hasil Penelitian}

Secara sederhana anak yang berhadapan dengan hukum dapat dikategorikan anak konflik hukum, dalam hal ini anak sebagai pelaku tindak pidana/kejahatan dan anak sebagai korban tindak pidana serta sebagai saksi korban. Pengertian anak dalam Undang-Undang tentang Perlindungan Anak, dikatakan bahwa anak adalah seseorang yang belum berusia 18 (delapan belas) tahun, termasuk anak yang masih dalam kandungan.

Anak yang berhadapan dengan hukum rentan sekali terhadap perlakuan-perlakuan yang tidak patut dan tidak sesuai dengan psikis atau kejiwaan anak tersebut. Untuk itulah perlu adanya perlindungan terhadap anak yang mengalami kasus-kasus tindak pidana/konflik dengan hukum. Tindak pidana adalah pelanggaran terhadap hukum pidana dimana sering diungkapkan oleh para pakar pidana bahwa hukum pidana itu ibarat pedang bermata dua atau ada ungkapan lain yang mengatakan hukum pidana itu akan mengiris dagingnya sendiri ketika salah dalam penerapannya. Ungkapan tersebut sangat tepat untuk menggambarkan bahwa hukum pidana itu sangat mengerikan. Barang siapa terperiksa, tertuntut secara hukum pidana, apalagi menjadi terpidana, dia tidak akan enak makan, tidak akan nyenyak tidur. Bahkan bukan hanya dirinya yang menderita, tetapi juga sanak keleuarganya akan turut mengalami imbas penderitaan itu. Masa depannya diujung kesuraman dan perpeluang kehidupannya tersengkirkan karena telah mendapat stigma dari masyarakat. Oleh sebab itu peringatan para pakar hukum pidana sejak beratus-ratus tahun lalu bukan sekedar pesan moral saja, tetapi lebih sebagai kewajiban etis bagi para penegak hukum agar menggunakan hukum pidana secara hati-hati dan secermat mungkin serta tidak sembarangan dan diskriminatif (Sholehuddin, 2007).

Di dalam menghadapi anak berhadapan dengan hukum, maka yang perlu diperhatikan dan dilaksanakan adalah:

1. Perlakuan atas anak secara manusiawi sesuai dengan martabat dan hak-hak anak.

2. Penyediaan petugas pendamping khusus anak sejak dini.

3. Penyediaan sarana dan prasarana khusus.

4. Penjatuhan sangsi yang tepat untuk kepentingan yang terbaik bagi anak.

5. Pemantauan dan pencatatan terus-menerus terhadap perkembangan anak yang berhadapan dengan hukum.

6. Pemberian jaminan untuk mempertahankan hubungan dengan orang tua atau keluarga.

7. Perlindungan dari pemberitaan identitas melalui media massa dan untuk menghindari labelisasi.

Sementara apabila anak yang menjadi korban tindak pidana, maka yang harus dilaksanakan adalah:

1. Upaya rehabilitasi, baik dalam lembaga maupun di luar lembaga. 
ZAHRA: Research And Tought Elmentary School Of Islam Journal Vol. (1 ) (1), (Maret)(2020), (Halaman)(1-7)| 4

2. Upaya perlindungan dari pemberitaan identitas melalui media massa dan untuk menghindari lebelisasi.

3. Pemberian jaminan keselamatan bagi saksi korban dan saksi ahli, baik fisik, mental, maupun sosial.

4. Pemeberian aksesibilitas untuk mendapatkan informasi mengenai perkembangan perkara

Terkait pemidanaan terhadap anak berhadapan dengan hukum, maka perlu adanya suatu model pemidanaan yang mengandung aspek-aspek sebagai berikut, yaitu bahwa hukum yang diterapkan pada anak tersebut harus baik dengan tujuan agar makna pemidanaan tidak ada unsur pembalasan dan mempunyai nilai filosofis yang agung. Berikutnya pemidanaan harus mengandung aspek ketepatan, artinya pemidanaan tersebut bisa memberi nilai manfaat yang berimplikasi pada sisi sosiologis, dan terakhir pemidanaan harus mengandung aspek kepastian hukum sehingga tidak bertentangan dengan kaidah-kaidah normatif dalam hukum positif. Untuk itu menurut hemat penulis pemidanaan yang tepat terhadap anak yang berhadapan dengan hukum adalah model restoratif justice. Model restoratif justice adalah secara sederhana dapat dikatakan sebagai suatu keadilan yang memulihkan atau dalam definisinya suatu proses dimana semua pihak yang terlibat dalam pelanggaaran tertentu bersama-sama untuk memecahkan secara kolektif bagaimana menghadapi akibat pelanggaran dan implikasinya diwaktu yang akan datang.

(Moh. Mahfud M. D., 2010) Terkait dengan barbagai kasus anak berhadapan dengan hukum serta penegakan hukum bagi pelaku masih dirasa ada pemahaman yang tidak sevisi aparat penegak hukum, akibatnya banya ketimpangan, bahkan ekses-ekses yang ditimbulkan lebih para penegak hukum, manakala moral dari para penegak hukum sudah luntur dan dapat digadaikan dengan suatu kepentingan yang bernilai pragmatis. Harus diakui secara jujur bahwa dalam kenyataannya bobroknya dunia peradilan di Indonesia bukan semata-mata dipengaruhi oleh politik dan kekuatan eksekutif, tetapi malah dalam porsi terbesar lebih banyak disebabkan oleh persoalan moral.

Sudah saatnya dunia kita harus diisi atau ada orang-orang yang mempunyai keberanian untuk mendobrak cara berhukum yang hanya menurut teks undang-undang dan berdasarkan prosedur, cara berhukum model yang demikian ini adalah cara yang paling mudah, sederhana dan dianggap paling aman untuk dijalankan sambil menunggu datangnya hari pensiun. Hal ini sangat bertentangan dengan kondisi yang ada, dimana saat ini dibutuhkan para penegak hukum yang benar-benar mempunyai jiwa pendobrak sebagaimana hukum itu sendiri yang mempunyai kekuatan untuk mendobrak agar dapat keluar dari kemandekan, untuk itu dibutuhkan para vigante/pejuang dalam penegakan hukum (Satjipto Raharjo, 2010).

Tidak mudah memang untuk menghadirkan suasana penegakan hukum yang benar-benar memenuhi rasa keadilan, ketepatan, dan kebenaran dalam masyarakat, tetapi juga tidak mustahil hal tersebut dapat dilakukan manakala ada upaya sungguh-sungguh dan komitmen yang kuat dari segenap aparat penegak hukum untuk berbenah diri dari keterpurukan penegakan hukum yang selama ini 
ZAHRA: Research And Tought Elmentary School Of Islam Journal Vol. (1 ) (1), (Maret)(2020), (Halaman)(1-7)| 5 sudah jauh dari harapan masyarakat, bahkan seperti sudah tidak ada kepercayaan masyarakat terhadap aparat penegak hukum di republik ini.

Banyak contoh ungkapan-ungkapan yang dimunculkan dalam dunia hukum yang berupa anekdot/plesetan/sindiran yang mempunyai penafsiran terhadap potret/fenomena yang sering terjadi dalam penegakan hukum, misalnya:

1. Kalau berperkara di pengadilan itu ibarat mengejar kambing tetapi kehilangan sapi.

2. Asas beracara di pengadilan itu adalah sederhana, cepat dan beaya ringan kenyataannya justru rumit dan berbelit, lama dan beaya mahal. 3

3. UUD diplesetkan Ujung-Ujungnya Duit.

4. KUHP diplesetkan Kasih Uang Habis Perkara.

5. Hakim diplesetkan Harus Kita Manfaatkan.

6. JPU diplesetkan Janji Pakai Uang. 7

7. Polisi diplesetkan Pakai Otak Lihat Situasi.

8. Pengacara diplesetkan Penghasilan Dengan Segala Cara, dan masih banyak istilah lainnya.

Melihat kondisi sseperti ini sungguh sangat ngeri penegakan hukum di republik ini, bahkan sudah tidak asing lagi bahwa penegakan hukum di negeri ini seperti pisau yang hanya tajam ke bawah tetapi begitu ke atas menjadi tumpul, ketika menyentuh orang-orang yang berduit dan yang memiliki kekuasaan. Hukum dan aparat penegak hukum sudah condong memihak pada kepentingan yang bersifat praktis sehingga nilai keadilan dari hukum itu telah sirna.

(Johnny Ibrahim, 2009) Secara teori memang hukum merupakan produk politik/kekuasaan karena kekuasaan merupakan sarana membentuk hukum, tetapi jangan diartikan yang lebih naif lagi, yaitu bahwa hukum adalah anak kandung politik sehingga keberadaannya harus mengabdi pada kepentingan politik karena telah dilahirkan melalui proses politik. Justru hukum harus lepas dari belenggu politik dan bisa menunjukkan bahwa hukum harus mengabdi pada keadilan karena hukum itu ada untuk memperjuangkan dan menghadirkan keadilan di tengah masyarakat. Jean Bodin pernah mengatakan bahwa hukum tanpa keadilan dapat disamakan dengan badan tanpa jiwa, seperti zombie yang gentayangan mencari korban.

Terhadap kasus-kasus yang ada, khususnya pada anak-anak sudah saatnya harus diakhiri caracara pemidanaan yang merusak masa depan anak yang tidak manusiawi karena melanggar hak asasi manusia dan cara-cara penegakan hukum yang tidak mencerminkan nilai keadilan sebagai tujuan pokok dari hukum itu sendiri. Sudah selayaknya cara-cara penegakan hukum yang menjunjung nilainilai keadilan yang substansial harus menjadi perhatian, dan tidak hanya sisi prosedural yang selalu dikedepankan dengan alasan demi kepastian hukum (M.Wahyudin Husein dan Hufron, 2008), tapi mencederai rasa keadilan. Memang dibutuhkan suatu keberanian untuk menghadirkan sebuah keadilan ditengah masyarakat yang telah lama terkoyak karena berbagai kepentingan yang bersifat prakmatis. Hal ini bisa kita rasakan dan kita lihat ketika suatu proses hukum yang berlangsung di 
ZAHRA: Research And Tought Elmentary School Of Islam Journal Vol. (1 ) (1), (Maret)(2020), (Halaman)(1-7)| 6 pengadilan ternyata hasilnya tidak seiring dengan keadilan yang ada ditengah masyarakat, disini berarti ada yang salah dalam penegakan hukum.

Berbagai kasus yang ada terutama yang terkait dengan suatu pelanggaran hukum yang dilakukan anak-anak sering menimbulkan suatu problem hukum. Aparat penegak hukum sering tidak ada kesamaan dalam penindakan terhadap pelanggaran yang dilakukan oleh anak-anak. Regulasi yang dijadikan pedoman dalam penanganan kasus anak-anak sering disimpangi bahkan belum dipahami secara mendalam oleh aparat dilapangan, sehingga terjadi pelanggaran terhadap hak asasi anak-anak dan tidak jarang merusak masa depan anak.

Restorative justice atau suatu keadilan yang memulihkan adalah sebuah sarana untuk mencari solusi terhadap pelanggaran hukum yang dilakukan oleh anak-anak yang karena dari sisi usia dan kejiwaan dirasa masih belum bisa disejajarkan atau dimintai pertanggungjawaban seperti orang dewasa. Model sanksi yang bersifat restorative justice adalah mengedepankan kepentingan masa depan anak yang berhadapan dengan hukum. Anak jangan sampai kehilangan masa depannya akibat sebuah stigma yang kurang baik yang bisa mempengaruhi kehidupannya yang masih panjang dan potensi sebagai generasi penerus bangsa.

\section{Simpulan}

Anak adalah amanah dan karunia Tuhan Yang Maha Esa, yang dalam dirinya melekat harkat dan martabat sebagai manusia seutuhnya. Didalam undang-undang perlindungan Anak dikatakan bahwa seseorang yang belum berusia 18 tahun termasuk anak yang masih dalam kandungan. Bagi anak-anak yang berhadapan dengan hukum rentan sekali terhadap perlawanan-perlawanan yang tidak patut dan dapat mempengaruhi faktor psikis/kejiwaan seorang anak. Peringatan para pakar-pakar hukum pidana bukan hanya sekedar pesan moral saja, akan tetapi lebih sebagai kewajiban yang etis bagi penegak hukum agar menggunakan hukum secara cermat. Agar tidak membuat kasus-kasus anak yang harus berakhir dengan cara-cara pemindanaan yang merusak masa depan anak karena itu semua dapat melanggar hak asasi manusia. Saat ini sudah saatnya dunia harus diisi dengan orang-orang yang mempunyai keberanian untuk mendobrak cara berhukum berdasarkan prosedur, menurut undangundang.

\section{Daftar Pustaka}

Ibrahim, J. (2009). Pendekatan ekonomi terhadap hukum, teori dan implikasi penerapannya dalam penegakan hukum. Surabaya: ITS Press.

Husein, M. W., \& Hufron. (2008). Hukum, Politik dan Kepentingan. Yogyakarta: Laks Bang PRESS indo.

(Jawa Pos: 2012)

Mahfud, Moh. M. D. (2010). Membangun politik hukum, menegakkan konstitusi. Jakarta: Rajawali Pers.

Raharjo, S. (2010). Penegakan hukum progresif. Jakarta: Kompas. 
ZAHRA: Research And Tought Elmentary School Of Islam Journal Vol. (1 ) (1), (Maret)(2020), (Halaman)(1-7)| 7 Sholehuddin. (2007). Modul Criminal Justice System. Surabaya.

(UUD No. 23 Tahun 2002) 